\title{
THE PRINCIPAL'S LEADERSHIP STYLE IN IMPROVING TEACHER PERFORMANCE
}

\author{
Jon Helmi \\ Sekolah Tinggi Agama Islam Hubbulwathan Duri, Riau, Indonesia \\ Email: jonhelmi_drsmp@gmail \\ Syukron Darsyah \\ Sekolah Tinggi Agama Islam Nurul Hidayah, Riau, Indonesia \\ Email: sukron.cuklon@gmail.com
}

DOI: 10.35445/alishlah.v11i2.121

Accepted: April 4 ${ }^{\text {th }}, 2019$. Approved: November 13 ${ }^{\text {rd }}, 2019$. Published: December $30^{\text {th }}, 2019$

\begin{abstract}
This study aims to determine the effect of the principal's leadership style on teacher performance. This research is a qualitative descriptive study. The location of the study was conducted in MTs Asy-syafi'iyah Pinggir, Bengkalis Regency, Riau. The subjects of this research are leadership directing and teacher performance. The objects of research are the teacher and the principal. In this case the researcher took a sample of 1 principal and 17 teachers. The researcher uses a total sampling technique or takes all subjects as a sample. To capture the data in this study, the researcher use several techniques, namely observation, interviews, questionnaires, and literature review. The results showed that the implementation of leadership style influenced the quality of education in MTs AsySyafi'iyah Pinggir. The leadership style is often used by principals in MTs AsySyafi'iyah Pinggir is democratic leadership. Democratic leadership style is the style of leader who gives broad authority to subordinates. Whenever there is a problem always include subordinates as a whole team. In a democratic leadership style the leader provides a lot of information about the tasks and responsibilities of his subordinates. Teacher performance in MTs Asy-Syafi'iyah Pinggir that the performance of a teacher can be improved if there is a match between work and his expertise, as well as the placement of teachers in their assignments.
\end{abstract}

Keywords: Principal's Leadership, Teacher Performance, Democratic Leadership 


\title{
GAYA KEPEMIMPINAN KEPALA SEKOLAH DALAM MENINGKATKAN KINERJA GURU
}

\begin{abstract}
Abstrak
Penelitian ini bertujuan untuk mengetahui pengaruh gaya kepemimpinan kepala sekolah terhadap kinerja guru. Penelitian ini merupakan penelitian deskriptif kualitatif. Lokasi penelitian dilakukan di MTs Asy-syafi'iyah Pinggir, Kabupaten Bengkalis, Riau. Subjek penelitian ini adalah kepemimpinan directing dan kinerja guru. Objek penelitian adalah guru dan kepala sekolah. Dalam hal ini, peneliti mengambil sampel sebanyak 1 orang kepala sekolah dan 17 orang guru. Penulis menggunakan teknik total sampling atau mengambil semua subjek sebagai sampel. Untuk menjaring data dalam penelitian ini, penulis menggunakan beberapa teknik, yaitu observasi, interview, angket, dan telaah pustaka. Hasil penelitian menunjukkan bahwa pelaksanaan gaya kepemimpinan berpengaruh terhadap kualitas pendidikan di MTs Asy-Syafi'iyah Pinggi. Gaya kepemimpinan yang sering digunakan oleh kepala sekolah di MTs Asy-Syafi'iyah Pinggir adalah gaya kepemimpinan demokratis. Gaya kepemimpinan demokratis adalah gaya pemimpin yang memberikan wewenang secara luas kepada para bawahan. Setiap ada permasalahan selalu mengikutsertakan bawahan sebagai suatu tim yang utuh. Dalam gaya kepemimpinan demokratis, pemimpin memberikan banyak informasi tentang tugas serta tanggung jawab para bawahannya. Kinerja guru di MTs AsySyafi'iyah Pinggir dapat ditingkatkan bila ada kesesuaian antara pekerjaan dengan keahliannya, begitu pula halnya dengan penempatan guru pada bidang tugasnya.
\end{abstract}

Kata Kunci: Kepemimpinan Kepala Sekolah, Kinerja Guru, Kepemimpinan Demokratis

\section{PENDAHULUAN}

Guru, sebagai tenaga pendidik, memiliki tugas dalam mengelola kegiatan belajar bagi siswa. Pengelolaan kegiatan belajar dan pembelajaran membutuhkan keahlian. Keahlian bagi guru saat ini sangat diperhatikan oleh pemerintah melalui berbagai kegiatan. Hal itu dilakukan untuk meningkatkan keahlian yang dimiliki oleh tenaga pendidik. Guru, sebagai tenaga pendidik, merupakan pengganti orang tua bagi siswa untuk mencapai tujuan pendidikan. Pengelolaan yang diperuntukkan bagi tenaga pendidik, baik kepala sekolah, guru bidang studi, maupun guru kelas, dilaksanakan sesuai perencanaan dari pemerintah.

Pelaksanaan kinerja guru dalam kesehariannya harus selalu mendapatkan pengawasan oleh pimpinan, yang dalam hal ini dilakukan oleh kepala sekolah. Peranan kepala sekolah dalam meningkatkan kinerja guru merupakan hal penting dan harus selalu diperhatikan. Pengelolaan pengajaran serta persiapan berbagai 
hal yang berkaitan dengan pembelajaran terkadang sering tertinggal dan tidak dilaksanakan oleh guru secara keseluruhan. Guru kerap tidak berpedoman dengan buku panduan atau perencanaan yang telah dirancang sebelumnya ketika mengajar. Guru jarang memperhatikan kebutuhan siswa dalam pembelajaran.

Pengelolaan dapat diartikan sebagai suatu pengurusan dalam manajemen pendidikan yang menjadi proses tercapainya tujuan pendidikan. Proses itu dimulai dari perencanaan, pengorganisasian, pengarahan, pemantauan, dan penilaian. Perencanaan meliputi kegiatan dalam menetapkan apa yang ingin dicapai dan bagaimana mencapainya, serta berapa lama, berapa orang, dan berapa banyak biayanya yang diperlukan. Perencanaan itu dibuat sebelum suatu tindakan dilaksanakan. Pengorganisasian diartikan sebagai kegiatan pembagian tugas kepada orang yang terlibat dalam kerja sama pendidikan tersebut, Karena tugastugas itu banyak dan tidak dapat diselesaikan oleh satu orang.

Lemahnya cara kerja guru berdampak buruk terhadap hasil yang didapat oleh siswa. Apalagi yang berada di daerah pedesaan, hampir tidak tersentuh oleh pengawasan secara menyeluruh. Kurangnya perhatian terhadap kinerja atau tata cara mengajar guru harus secepatnya untuk diubah.

Untuk itu, peneliti merasa perlu megkaji gaya kepemimpinan kepala sekolah di MTs Asy-syafi'iyah Pinggir. Sebagai lembaga pendidikan swasta yang berada di bawah naungan yayasan pendidikan Islam, pada awal berdirinya, lembaga pendidikan ini telah melaksanakan pembelajaran sesuai dengan kurikulum dari Departemen Agama dan Departemen Pendidikan dan Kebuadayaan. Hal ini perlu dilakukan karena lembaga pendidikan agama menjadi tumpuan harapan para orang tua dalam membina anak-anak mereka agar memiliki ilmu pengetahuan dan agama yang baik. Untuk mencapai hal itu, tentunya sistem pembelajaran di sekolah harus sesuai dengan aturan yang telah ditetapkan.

Pendidikan yang baik di suatu satuan pendidikan dipengaruhi juga oleh gaya kepemimpinan kepala sekolah. Kepemimpinan kepala sekolah berkenaan dengan kemampuan dan kompetensinya, baik hard skill maupun soft skills, untuk mempengaruhi seluruh sumber daya sekolah agar mampu mencapai tujuan dan sasaran yang telah ditetapkan sekolah. Kepemimpinan kepala sekolah yang efektif adalah kepemimpinan yang mampu memberdayakan seluruh potensi yang ada di sekolah dengan optimal, sehingga guru, staf, dan pegawai lainnya merasa ikut terlibat dalam pencapaian tujuan dan sasaran yang telah ditetapkan oleh sekolah. Kepemipinan kepala sekolah yang efektif adalah kepemimpinan yang mampu memberikan kepuasan bagi stakeholders sekolah serta mampu memberikan inspirasi dan teladan yang baik bagi guru, staf, dan pegawai lainnya (Karyawati dan Priansa, 2013: 164)

Kepala sekolah selaku pimpinan harus menguasai sistem manajemen kelembagaan dunia pendidikan. Seorang kepala sekolah yang tidak dapat 
mengatur anak buah (guru dan karyawan) akan menghambat kelancaran proses pembelajaran. Kepala sekolah yang efektif merupakan pemimpin yang mampu mengombinasikan kedua fungsi tersebut dengan optimal. Sebagai pimpinan dari suatu lembaga pendidikan, kepala sekolah menjadi tombak kepemimpinan tersebut. Kepala sekolah memberikan bimbingan dan binaan serta arahan kepada seluruh guru yang berada pada lingkungan pendidikan tersebut, terutama dalam mengatasi permasalahan pendidikan dan meningkatkan kualitas pendidikan. Kualitas pendidikan dalam hal ini adalah hasil belajar yang didapat siswa setelah mengikuti proses pembelajaran (Helmi, 2018).

Gaya kepemimpinan dapat dikelompokkan menjadi 4, yaitu mengarahkan (directing), melatih (coaching), partisipasi (participation), dan kendali bebas (delegating). Gaya kepemimpinan yang mengarahkan merupakan respons kepemimpinan yang perlu dilakukan oleh manajer pada kondisi karyawan lemah dalam kemampuan, minat, dan komitmennya karena organisasi menghendaki penyelesaian tugas-tugas yang tinggi. Gaya kepemimpinan yang melatih terlihat saat karyawan menghadapi kesulitan dalam menyelesaikan tugas. Mereka kerap takut untuk mencoba melakukannya. Untuk itu, manajer harus membagi struktur tugas sesuai kemampuan dan tanggung jawab karyawan. Gaya kepemimpinan partisipasi, adalah respons manajer yang harus diperankan ketika karyawan memiliki tingkat kemampuan yang cukup, tetapi tidak memiliki kemauan untuk melakukan tanggung jawab. Selanjutnya, untuk tingkat karyawan dengan kemampuan dan kemauan yang tinggi, gaya kepemimpinan yang sesuai adalah gaya kendali bebas (Wahyudi, 2012).

Sebagai seorang pemimpin pada suatu lembaga pendidikan, kepala sekolah membutuhkan perspektif sebagai berikut.

a. Visi dan simbol. Guru kepala atau kepala seolah harus mengomunikasikan nilai-nilai institusi kepada staf, siswa, dan masyarakat luas;

b. Gaya kepempinan;

c. Dekat dengan pelanggan anak didik;

d. Pengalaman;

e. Menciptakan rasa kekeluargaan;

f. Rasa sebagai keseluruhan, ritme, keinginan kuat, intensitas, dan antusias ( Rohiat, 2010: 36).

Kepemimpinan timbul karena adanya followership yang melakukan kerja sama dalam rangka mencapai tujuan yang telah ditentukan bersama. Dengan adanya tujuan-tujuan tertentu timbul kerja sama. Seorang pimpinan harus mengatur hal ini. Seorang pemimpin dalam aktivitasnya membimbing, mengontrol, dan mengarahkan tindakan orang lain untuk menuju suatu sasaran tertentu. Kemampuan seseorang dalam kepemimpinanya adalah skill. Orang yang 
memiliki keinginan dan motivasi dapat lebih mampu menguasainya (B. Suryosubroto, 2002: 3).

Tugas guru dalam pembelajaran salah satunya adalah mampu membentuk akhlak atau tingkah laku siswa menjadi lebih baik dari hari ke hari. Hal ini sesuai dengan pernyataan dari Hamdani bahwa "pembelajaran secara umum adalah kegiatan yang dilakukan guru sehingga tingkah laku siswa berubah ke arah yang lebih baik, pembelajaran adalah upaya guru menciptakan iklim dan pelayanan terhadap kemampuan, potensi, minat, bakat, dan kebutuhan siswa yang amat beragam agar terjadi interaksi optimal antara guru dan siswa serta antar siswa" (Hamdani, 2011: 72).

Kinerja guru merupakan kemampuan seorang guru dalam melaksanakan tugas pembelajaran di madrasah atau sekolah dan bertanggung jawab atas peserta didik di bawah bimbingannya dengan meningkatkan prestasi peserta didik. Oleh karena itu, kinerja guru ini dapat diartikan sebagai suatu kondisi yang menunjukkan kemampuan seorang guru dalam menjalankan tugasnya serta menggambarkan adanya suatu perbuatan yang ditampilkan guru selama melakukan aktivitas pembelajaran. Faktor-faktor yang mempengaruhi kinerja, yaitu lingkungan, perilaku manajemen, desain jabatan, penilaian kinerja, umpan balik, dan administrasi pengupahan (Supardi, 2013). Dengan demikian, dapat diartikan bahwa kinerja pegawai sangat dipengaruhi oleh karakteristik individu yang terdiri atas pengetahuan, keterampilan, kemampuan, motivasi, kepercayaan, nilai-nilai, serta sikap.

Kinerja seseorang dapat ditingkatkan bila ada kesesuaian antara pekerjaan dengan keahliannya. Begitu pula halnya dengan penempatan guru pada bidang tugasnya. Menempatkan guru sesuai dengan keahliannya secara mutlak harus dilakukan. Bila guru diberikan tugas tidak sesuai dengan keahliannya akan berakibat menurunnya cara kerja dan hasil pekerjaan, juga menimbulkan rasa tidak puas pada diri guru tersebut. Rasa kecewa akan menghambat perkembangan moral kerja guru. Menurut Danim (2010), moral kerja positif ialah suasana bekerja yang gembira, bekerja bukan dirasakan sebagai sesuatu yang dipaksakan melainkan sebagai sesuatu yang menyenangkan. Moral kerja yang positif adalah mampu mencintai tugas sebagai sesuatu yang memiliki nilai keindahan di dalamnya. Jadi, kinerja dapat ditingkatkan dengan cara memberikan pekerjaan seseorang sesuai dengan bidang kemampuannya.

Menilai kualitas kinerja dapat ditinjau dari beberapa indikator yang meliputi unjuk kerja, penguasaan materi, penguasaan profesional keguruan dan pendidikan, penguasaan cara-cara penyesuaian diri, dan kepribadian untuk melaksanakan tugasnya dengan baik (Sagala, 2009). Kinerja guru sangat penting untuk diperhatikan dan dievaluasi karena guru mengemban tugas profesional, artinya tugas-tugas hanya dapat dikerjakan dengan kompetensi khusus yang 
diperoleh melalui program pendidikan. Dari uraian tersebut dapat disimpulkan indikator kinerja guru antara lain kemampuan membuat perencanaan dan persiapan mengajar, penguasaan materi yang akan diajarkan kepada siswa, penguasaan metode dan strategi mengajar, pemberian tugas-tugas kepada siswa, pengelolaan kelas, serta penilaian dan evaluasi.

Kinerja guru dan gaya kepemimpinan kepala sekolah menjadi dua hal yang tidak dapat dipisahkan. Kepala sekolah yang disegani dan dihormati oleh para guru akan membuat suasana di satuan pendidikan menjadi kondusif. Suasana yang kondusif tentunya akan mendorong peningkatan kualitas proses belajar mengajar di sekolah tersebut. Berdasarkan latar belakang tersebut, penelitian ini dilakukan untuk mengetahui pengaruh gaya kepemimpinan kepala sekolah di MTs Asy-Syafi'iyah Pinggir, Kabupaten Bengkalis, Riau, terhadap kinerja gurunya.

\section{METODE PENELITIAN}

Penelitian ini merupakan penelitian deskriptif kualitatif. Penelitian dilakukan pada bulan Februari hingga Mei 2018. Lokasi penelitian dilakukan di MTs Asy-syafi'iyah Pinggir. Subjek penelitian ini adalah kepemimpinan directing dan kinerja guru. Objek penelitian adalah guru dan kepala sekolah. Dalam hal ini, peneliti mengambil sampel sebanyak 1 orang kepala sekolah dan 17 orang guru. Peneliti menggunakan teknik total sampling atau mengambil semua subjek sebagai sampel.

Untuk menjaring data dalam penelitian ini, peneliti menggunakan beberapa teknik, yaitu observasi, interview, angket, dan telaah pustaka. Setelah data terkumpul. data tersebut dianalisis dari kualitatif menjadi kuantitatif, lalu dituangkan dalam bentuk tabel dengan persentase angka-angka. Hasil dari evaluasi siswa dianalisis dengan menggunakan formula Wayan dan P.P.N. Sumartana, yaitu nilai yang diberikan berdasarkan jumlah jawaban yang benar dibagi jumlah dari keselurahan soal, kemudian dikalikan dengan 100.

\section{HASIL DAN PEMBAHASAN}

Sekolah ini didirikan dengan diawali oleh niat para pengurus Masjid Raya Pasar Duri untuk meningkatkan sumber daya manusia di lingkungan jamaah masjid secara khusus dan lingkungan masyarakat Kecamatan Mandau umumnya. Pada saat itu, masyarakat terpikir untuk mendirikan lembaga pendidikan formal. Kemudian, didirikanlah Yayasan Asy-syafi'iyah dengan akta notaris Hamzentori SH pada tanggal 8 Juni 1993. Sebelum yayasan didirikan, sudah ada lembaga 
pendidikan nonformal di lokasi itu berupa madrasah diniyah awaliyah (MDA) yang dikelola oleh pengurus Masjid Raya Pasar Duri dengan gedung permanen yang berukuran $7 \times 28 \mathrm{~m}$ bertingkat dua.

Lembaga pendidikan MTs Asy-syafi'iyah dirikan dengan izin Kanwil Departemen Agama Nomor C-IV/PP03.2/07/1975 dan kemudian diperbaharui dengan Nomor Kd.04.03/04/PP.00/2010. Sekolah ini mulai pindah ke Kecamatan Pinggir pada 2004 dan telah terakreditasi pada 2008.

Untuk mengetahui gaya kepemimpinan kepala sekolah dalam meningkatkan kinerja guru di MTs Asy-Syafi'iyah Pinggir ini adalah sebagai berikut. Tiap-tiap pertanyaan diberi tiga opsi, setiap opsi diberi bobot sebagai berikut.

1. Alternatif pilihan A, bobotnya 4

2. Alternatif pilihan $\mathrm{B}$, bobotnya 3

3. Alternatif pilihan $\mathrm{C}$, bobotnya 2

4. Alternatif pilihan $\mathrm{D}$, bobotnya 1

\section{Paparan data gaya kepemimpinan otoriter}

Menurut guru, pengawasan terhadap lingkungan sekolah dan peserta didik merupakan hal penting yang harus dilaksanakan. Selain melakukan pengawasan, guru juga memperkenalkan lingkungan sekolah. Pengenalan lingkungan dilaksanakan pada awal masuk sekolah yang dikenal dengan kegiatan orientasi sekolah. Pengenalan lingkungan itu meliputi lingkungan rumah, sekolah, masyarakat, dan alam sekitar, serta lingkungan yang lebih luas. Hal ini diharapkan dapat menunjang proses penyesuaian diri peserta didik dengan lingkungan yang dimaksud serta dapat dimanfaatkan untuk pengembangan diri secara mantap dan berkelanjutan. Selain itu, bimbingan dalam rangka merencanakan masa depan perlu juga diakukan. Tujuannya adalah agar peserta didik mampu mempertimbangkan dan mengambil keputusan tentang masa depan dirinya sendiri, baik yang menyangkut bidang pendidikan, karier, maupun budaya/keluarga/kemasyarakatan.

Dalam mengajar, guru harus mengikuti jadwal yang telah ditentukan, yaitu Senin hingga Sabtu. Proses pembelajaran di MTs Asy-syafi'iyah ini belum mengikuti program fullday. Ketika guru melaksanakan kegiatan pembelajaran, guru disupervisi oleh kepala sekolah. Para guru melaksanakan tugas meningkatkan kegiatan belajar dengan memberi pengajaran. Sesungguhnya, pengajaran dapat didefinisikan sebagai seperangkat peristiwa yang dirancang untuk memprakarsai, menggiatkan, dan mendukung kegiatan belajar siswa (manusia yang belajar). Belajar mengajar adalah suatu kegiatan yang bernilai edukatif. Nilai edukatif mewarnai interaksi yang terjadi antara guru dan anak didik. Interaksi yang bernilai edukatif dalam kegiatan belajar mengajar dilakukan 
untuk mencapai tujuan tertentu yang telah dirumuskan sebelum pengajaran berlangsung. Guru dengan sadar merencanakan kegiatan pengajaran secara sistematis dengan memanfaatkan segala sesuatunya guna kepentingan pengajaran.

\section{Paparan data gaya kepememimpinan demokratis}

Berdasarkan jawaban responden, alternatif jawaban tertinggi adalah sangat sering dilaksanakan arahan dan bimbingan mengenai kualitas pendidikan di MTs Asy-syafi'iyah. Hal ini terlihat pada persiapan mengajar guru yang dilaksanakan pada awal pembelajaran yang dituangkan dalam pembuatan rencana pembelajaran. Perencanaan pembelajaran dibuat berdasarkan arahan dari sistem kurikulum. Dalam kegiatan proses pembelajaran, kurikulum sangat dibutuhkan. Kurikulum adalah pedoman untuk menyusun target dari pembelajaran.

Untuk itu, berikut ini dikemukaan beberapa pengertian kurikulum tersebut.

1. Kurikulum adalah suatu perencanaan yang tidak hanya berupa perencanaan mental saja, tetapi pada umumnya diwujudkan dalam bentuk tulisan.

2. Kurikulum bukanlah kegiatan, melainkan perencanaan atau rancangan kegiatan.

3. Kurikulum berisi berbagai macam hal seperti masalah yang harus dikembangkan dalam diri siswa, evaluasi untuk menafsirkan hasil belajar, bahan, dan peralatan yang dipergunakan, kualitas guru yang dituntut, dan sebagainya.

4. Kurikulum melibatkan maksud atau tujuan pendidikan formal. Kurikulum sebagai perangkat organisasi pendidikanmenyatukan berbagai komponen, seperti tujuan, isi, dan sistem penilaian dalam satu kesatuan yang tak terpisah. Kurikulum adalah sebuah sistem.

Berdasarkan alternatif jawaban, mendatangkan pembicara dari luar sekolah hanya kadang-kadang saja dilaksanakan. Hal itu berkaitan dengan dana sekolah yang masih minim. Kemampuan guru dalam mengajar serta mengarahkan siswa terlihat pada peningkatan kinerja guru ketika berada di dalam kelas bersama anakanak. Dalam pelaksanaan pembelajaran, banyak hal yang dilakukan guru, seperti pengaturan kelas sebelum melakukan kegiatan pembelajaran yang bertujuan agar suasana belajar dapat tercipta secara nyaman dan teratur sehingga pembelajaran dapat berjalan secara efektif. Kegiatan kedua yang banyak mendapat respons dari siswa adalah bahwa guru memeriksa atau mengecek kehadiran siswa. Hal ini dapat terlihat pada tabel bahwa $64,70 \%$ guru megatakan kadang-kadang melakukan pengaturan kelas karena kelas sudah diatur pada awal pembelajaran. 
Berdasarkan alternatif jawaban dapat diketahui bahwa kepala sekolah sering mengadakan rapat kerja. Ketika guru menyampaikan materi pelajaran kepada siswa di dalam kelas, guru menemukan kejenuhan pada diri siswa. Maka, guru sering mengajak siswa bercanda sambil bercerita. Hal ini dirasakan efektif mengingatkan tingkat kejenuhan siswa dalam belajar sangat tinggi. Siswa sangat senang jika guru bercerita ditambah dengan humor yang disertai banyak nasihat. Kondisi belajar siswa yang demikian sangat dipahami oleh guru. Oleh karena itu, guru mengajak siswa belajar santai tetapi serius. Aktivitas lain yang dilakukan guru adalah mengajak siswa untuk bernyanyi dengan memerintahkan beberapa orang siswa maju ke depan kelas untuk menampilkan kebolehan mereka.

Berdasarkan alternatif jawaban tertinggi, kepala sekolah sangat sering memberikan pembinaan kurikulum, termasuk ketika guru mengajar di dalam kelas. Ia membina siswa agar bertanya kembali kepada guru jika ada yang belum memahami materi pelajaran. Hasil analisis menunjukkan bahwa 8 orang mengatakan bertanya kembali kepada guru jika ada yang belum dipahami. Namun, ada juga yang bertanya kepada teman yang telah paham, bahkan banyak yang diam saja. Guru harus terus memotivasi siswa untuk berani bertanya apabila belum atau tidak memahami materi yang disampaikan.

Berdasarkan alternatif jawaban responden tampak bahwa gaya kepemimpinan di MTs Asy-Syafi'iyah Pinggir adalah gaya kepemimpinan demokratis yang mengutamakan sistem directing atau mengarahkan. Sebagai kepala sekolah, yang dulunya berawal dari guru juga, Ibu Zuriati paham sekali keinginan yang diharapkan dalam suatu lembaga pendidikan. Ia mengatakan bahwa aktivitas yang sering dilakukan guru sambil menerangkan pelajaran adalah bercerita, bercanda, dan menasihati siswa. Kegiatan yang dilakukan sambil bercerita sangat disukai oleh siswa, terutama jika mereka merasa bosan terhadap pelajaran. Sementara, menasihati siswa untuk bertindak dan bertingkah laku yang baik sangat penting. Hal ini dilakukan guru agar terjalin hubungan yang harmonis antara guru dan siswa.Kendatipun demikian, pemberian nasihat dan belajar sambil bercanda ini hanya sesekali dilakukan guru mengingat jam pelajaran yang sangat terbatas.

Bahwa Gaya kepemimpinan otoriter kadang-kadang saja diterapkan oleh kepala sekolah. Hal ini diperoleh berdasarkan alternatif jawaban yang diberikan responden pada poin $\mathrm{C}$ yang merupakan jawaban tertinggi dengan persentase $64,70 \%$. Kegiatan belajar yang sering dilakukan guru adalah dengan mencatat pelajaran. Hal ini terlihat pada tingginya persentase jawaban responden, yaitu 64,70\%. Kegiatan mencatat sebenarnya kurang sesuai dengan kurikulum tingkat satuan pendidikan. Namun, hal ini tetap dilakukan guru mengingat bahwa buku paket pelajaran yang tersedia di sekolah hanya sedikit dan kemauan orang tua siswa maupun siswa yang bersangkutan untuk membeli buku pelajaran sangat 
rendah. Maka, agar proses pembelajaran tetap berjalan, guru mengambil inisiatif untuk mencatat dan mendiktekan pelajaran. Kegiatan mencacat terkadang diselingi guru dengan aktivitas ceramah sambil menerangkan pelajaran.

Belajar adalah suatu kegiatan anak didik dalam menerima, menanggapi, dan menganalisis bahan-bahan pelajaran yang disajikan oleh pengajar, yang berakhir pada kemampuan untuk menguasai bahan pelajaran yang disajikan itu. Pada definisi tersebut, belajar dianggap sebagai perubahan-perubahan psikologis yang tidak dapat dibuktikan atau disangkal kebenarannya. Akan tetapi, kenyataannya adalah bahwa perubahan itu terjadi pada salah satu bahagian dari organisme, yakni hanya sistem urat saraf. Dari beberapa definisi yang dikemukakan di atas dapat dipahami bahwa belajar adalah aktivitas yang menghasilkan perubahan pada individu, baik aktual maupun potensial. Perubahan tersebut pada pokoknya berupa perubahan kemampuan baru yang belaku dalam waktu yang relatif lama.

Dalam rangka pencapaian tujuan pengajaran, usaha guru sangat diperlukan untuk menciptakan kondisi belajar yang efektif dan optimal. Seperti yang dikatakan oleh Uzer Usmar (2011) bahwa suatu kondisi belajar yang optimal dapat tercapai jika guru mampu mengatur siswa, sarana pengajaran mengendalikannya dalam suasana yang menyenangkan untuk mencapai tujuan pengajaran.

Berdasarkan alternatif jawaban bahwa jawaban tertinggi berada pada opsi A, yaitu $100 \%$, menunjukkan bahwa kepala sekolah menerapkan gaya kepimpinan demokratis dengan sistem tegur sapa pada setiap aktivitas belajar mengajar, baik kepada guru maupun kepada siswa. Guru adalah salah satu komponen manusiawi dalam proses belajar mengajar yang ikut berperan dalam usaha pembentukan sumber daya manusia yang potensial pada bidang pembangunan. Oleh karena itu, guru yang merupakan salah satu unsur di bidang kependidikan harus berperan serta secara aktif dan menempatkan kedudukannya sebagai tenaga profesional, sesuai dengan tuntutan masyarakat yang semakin berkembang. Dalam arti khusus dapat dikatakan bahwa pada setiap diri guru itu terletak tanggung jawab untuk membawa para siswanya pada suatu kedewasaan atau taraf kematangan tertentu. Dalam rangka ini, guru tidak semata-mata sebagai pengajar yang hanya melakukan transfer of knowledge, tetapi juga sebagai pendidik yang melakukan transfer of values dan sekaligus sebagai pembimbing yang memberikan pengarahan dan menuntun sistem belajar.

Berdasarkan alternatif jawaban, dapat diketahui bahwa kepala sekolah juga kadang-kadang menerapkan gaya kepemimpinan bebas (laissez faire). Dalam hal ini, biasanya kepala sekolah lebih banyak mengarahkan agar guru dapat mengambil inisiatif menggunakan waktu pembelajaran dengan materi yang tidak sesuai dengan kurikulum akibat banyaknya pokok bahasan yang harus 
disampaikan dan lambatnya siswa dalam memahami pelajaran. Pengunaan waktu pembelajaran terasa sangat sedikit jika guru berhadapan dengan pelajaran eksakta karena siswa kerap meminta guru menjelaskan kembali secara berulang-ulang. Hal ini merupakan faktor yang membuat penyampain pokok materi pelajaran kurang sesuai dengan jadwal yang telah ditentukan.

Berdasarkan alternatif jawaban responden dapat pula disimpulkan bahwa lingkungan sangat sering memberikan pengaruh terhadap kinerja guru. Kesempatan yang sering diberikan guru kepada siswa jika mengalami permasalahan dalam belajar adalah dengan memanggil orang tua siswa jika permasalahan membutuhkan perhatian orang tua. Hal ini dilakukan agar penerapan komuniasi yang efektif tetap terjalin, karena pengawasan orang tua sangat dibutuhkan dalam peningkatan kualitas belajar siswa.

Sebanyak 12 orang responden atau 70,58\% mengatakan bahwa perilaku manajemen sekolah sangat sering dilakukan. Jika siswa belum memahami pelajaran, sikap guru adalah memberikan bimbingan kepada siswa serta mengulanngi keterangan pelajaran. Jika telah berulang-ulang dilakukan tetapi siswa belum juga memahami pelajaran dengan baik, guru melakukan bimbingan di luar jam pelajaran. Hal ini dilakukan guru mengingat bahwa waktu pelajaran sangat terbatas, yaitu hanya 40x1 jam pelajaran. Aktivitas yang dilakukan guru ini sangat diinginkan oleh seluruh siswa, tetapi kadang tidak semua guru melakukan hal yang demikian, karena masing-masing karakter guru berbeda.

Dari jawaban para responden juga terlihat bahwa jika siswa telah mengikuti pembelajaran, guru akan memberikan gambaran penilaian kepada orang tua siswa. Pengiriman gambaran nilai ini bertujuan agar komuniasi tentang permasalahan dan perkembangan kegiatan pengawasan siswa lebih ditingkatkan. Arsip nilai diberikan guru melalui siswa, baik nilai yang baik, cukup baik, maupun yang membutuhkan perhatian orang tua.

Selain itu, ditemukan pula bahwa berbagai macam kesulitan yang dialami oleh siswa dapat diatasi dengan baik. Hal yang berkaitan dengan nilai, perkembangan sikap, serta laporan-laporan kegiatan siswa lainnya akan dipantau dan diawasi oleh orang tua dan guru. Menurut guru, hal ini berdampak pada peningkatan pencapaian siswa. Akan tetapi, berbagai kendala kerap pula ditemukan, yakni beberapa siswa yang tidak mau hadir saat guru melakukan bimbingan belajar. Sebelas responden mengatakan bahwa guru mengawasi kegiatan pembelajaran siswa, artinya sebanyak 64,70\% responden menyatakan bahwa guru mengadakan bimbinganbelajar. Jika siswa belum juga memahami pelajaran, guru kadang mencari contoh-contoh yang lain dengan tujuan agar siswa dapat memahami pelajaran dengan baik.

Pengawasan terhadap kegiatan pembelajaran siswa sangat baik jika dilakukan guru secara terus menerus. Jika kegiatan pembelajaran siswa diawasi 
oleh guru, pembelajaran akan berjalan efektif, karena siswa takut bermain-main saat kegiatan pembelajaran berlangsung. Namun, jika guru sering meningggalkan kelas sewaktu pembelajaran, aktivitas belajar siswa pun kurang efektif (Mulyasa, 2011).

Dalam analisis data tersebut, penulis melakukan perhitungan secara kualitatif dan kuantatif sesuai dengan jenis data yang disampaikan. Berdasarkan analisis data dapat diketahui bahwa nilai tertinggi ada pada opsi A, yaitu 215 poin dengan analisis $215: 4 \times 100 \%=53,75 \%$. Maka, dapat dikatakan bahwa gaya kepemimpinan kepala sekolah dalam meningkatkan kinerja guru berhasil secara baik. Gaya kempimpinan yang dominan atau sering digunakan oleh kepala sekolah adalah gaya kepimpinan demokratis dengan selalu mengarahkan atau mengaktifkan (directing).

Selain menyebarkan angket, peneliti juga melakukan wawancara kepada kepala sekolah dengan rangkaian pertanyaan. Jawaban yang diperoleh menunjukkan bahwa kepala sekolah sering melakukan pengawasan terhadap guru dan melakukan supervisi saat guru mengajar. Guru-guru juga sering dikirim untuk mengikuti pelatihan kurikulum. Namun, pihak sekolah belum pernah mendatangkan narasumber dari luar untuk membina para guru di sekolah. Rapat akhir semester juga merupakan agenda rutin di sekolah tersebut. Kepala sekolah menyatakan bahwa gaya kepemimpinan yang diterapkan adalah kepemimpinan demokratis sambil mengajak para guru untuk mendiskusikan permasalahan dan mencari solusi untuk menyelesaikannya. Pelaksanaan gaya kepemimpinan terhadap kualitas pendidikan di MTs Asy-Syafi'iyah Pinggir memberi pengaruh yang teramat besar. Gaya kepemimpinan demokrasi memberikan dampak yang sangat baik dalam melancarkan visi dan misi pendidikan serta meningkatkan kinerja guru di sekolah.

\section{SIMPULAN}

Gaya kepemimpinan demokratis adalah gaya pemimpin yang memberikan wewenang secara luas kepada para bawahan. Setiap ada permasalahan selalu mengikutsertakan bawahan sebagai suatu tim yang utuh. Dalam gaya kepemimpinan demokratis, pemimpin memberikan banyak informasi tentang tugas serta tanggung jawab para bawahannya. Sementara itu, kinerja seorang guru dapat ditingkatkan bila ada kesesuaian antara pekerjaan dengan keahliannya. Begitu pula halnya dengan penempatan guru pada bidang yang sesuai. Menempatkan guru sesuai dengan keahliannya secara mutlak harus dilakukan. Bila guru diberikan tugas tidak sesuai dengan keahliannya akan berakibat menurunnya cara kerja dan hasil pekerjaan mereka, juga akan menimbulkan rasa 
Al-Ishlah: Jurnal Pendidikan - ISSN: 2087-9490 (p); 2597-940X (e)

Vol. 11, No. 2 (2019)

tidak puas pada diri mereka.Tingkat pendidikan guru akan sangat mempengaruhi baik tidaknya kinerja guru. Kepala sekolah bertugas memberikan bimbingan, bantuan, pengawasan, dan penelitian pada masalah-masalah yang berhubungan dengan pengembangan pengajaran berupa perbaikan program dan kegiatan belajar mengajar. Sasaran supervisi ditujukan kepada situasi belajar mengajar yang memungkinkan terjadinya tujuan pendidikan secara optimal.

\section{DAFTAR PUSTAKA}

E. Mulyasa. (2011). Menjadi Guru Profesional. Rosda Karya. Jakarta.

Euis Karyawati dan Donni Juni Priansa. (2013). Kinerja dan Profesionalisme Kepala Sekolah. Alfabeta. Bandung.

Helmi, Jon. (2018). Implementasi Program Kerja Komite Sekolah di SMPN 12 Mandau. Al - Ishlah: Jurnal Pendidikan, 10(1).

Moh. Uzer Usman. (2011). Menjadi Guru Profesional, Rosda Karya, Bandung.

Rohiat. (2010). Manajemen Sekolah. PT Refika Aditama. Bandung.

Suryabrata, Sumadi. (2010). Psikologi Pendidikan. Raja Grafindo Persada, Jakarta.

Supardi. 2013. Kinerja Guru. Rajawali Persada. Jakarta.

Sudarwan, Danim. (2010). Kepemimpinan Pendidikan. Alfabeta. Bandung. Sagala,

Sagala. (2009). Kemampuan Profesional Guru dan Tenaga Kependidikan. Alfabeta. Bandung.

Wahyudi. (2012). Kepemimpinan Kepala Sekolah Dalam Organisasi Pembelajaran. Alfabeta. Bandung. 